DOI: 10.20472/IAC.2019.050.006

KAREL BRU゚NA

University of Economics, Prague, Czech Republic

\title{
CREDIT SUPPLY CONSTRAINT AND EXTERNAL SOLVENCY: THE CASE OF THE CZECH REPUBLIC
}

\begin{abstract}
:
The submission contains formal and empirical analyses of the constraints on the supply of credit in open transition economies as the external solvency of the economy and the banking sector is ensured when their international investment position is negative, foreign owners have significant participation in domestic banks, and banks face increasing regulatory requirements under Basel III. Our objective is to define the factors that affect constraints on the supply of credit at both the macro and banking level and to quantify the relationship between international investment sustainability determinants and the sources of foreign funding in the economy/banking system using an unrestricted ARDL ECM model in the Czech Republic.
\end{abstract}

\section{Keywords:}

net foreign assets, credit supply, external solvency, Basel III

JEL Classification: F32, F34, E51 